On the whole, the text is well written, nd the author is to be congratulated on carefully documented, thorough eport. Unfortunately, however, the ook shows signs of hasty printing, and complete proof-reading. Although a ew printing errors are almost hevitable, this book has too many for s length. Most of these are minor, lthough the gremlins of the type have dded two new species to the literature "Blackpool warbler'" and Yellowhafter Flicker, on pp. 51 and 66, espectively). Several of the footnotes are not cited in the text, and one (59) is missing from the Literature Cited. A few references are incomplete. One hopes that future publications of NPPAC will be more carefully checked before publishing, and that future works will not be double-spaced. Such excessive use of paper seems particularly inappropriate in a book published by a large conservation organization.

These criticisms are minor, and I unhesitatingly recommend this book to all concerned naturalists. - Martin $K$. McNicholl, Edmonton.

\title{
LOOKING BACK
}

\section{At Our Questionnaire}

We wish to thank the 215 people who took the trouble to reply to the questionaire in the March 1973 issue. We analyzed the first 200, 192 of which were cceived by the July 2 deadline. There were only two replies from people not urrently getting the Blue Jay.

references: The table presents a summary of what respondents want to read hore about.

\section{ubject \\ irds}

lowers, trees

onservation

ammals

nvironmental

problems

hotography

utterflies

eology

eptiles

ower Plants

mphibians

ish

leontology

ther Insects

ther

vertebrates

stronomy

ther

\begin{tabular}{|c|c|c|c|c|c|}
\hline $\begin{array}{l}\text { Total } \\
\text { wanting } \\
\text { subject }\end{array}$ & $\begin{array}{l}\text { Percent } \\
\text { of res- } \\
\text { pondents }\end{array}$ & $\begin{array}{l}\text { Indicated } \\
\% \text { of } \\
\text { material * }\end{array}$ & $\begin{array}{l}\text { Life } \\
\text { history, } \\
\text { ecology }\end{array}$ & $\begin{array}{l}\text { Local } \\
\text { lists }\end{array}$ & $\begin{array}{l}\text { Iden- } \\
\text { tifi- } \\
\text { cation } \\
\end{array}$ \\
\hline 149 & 75 & 10 & 129 & 106 & 111 \\
\hline 144 & 74 & 10 & 105 & 82 & 111 \\
\hline 140 & 70 & 10 & - & - & - \\
\hline 135 & 68 & 9 & 118 & 86 & 88 \\
\hline 113 & 57 & 8 & - & - & - \\
\hline 85 & 43 & 6 & - & - & - \\
\hline 83 & 42 & 6 & 61 & 46 & 60 \\
\hline 77 & 39 & 5 & - & - & - \\
\hline 74 & 37 & 5 & 56 & 53 & 50 \\
\hline 74 & 37 & 5 & 58 & 44 & 55 \\
\hline 72 & 36 & 5 & 55 & 47 & 52 \\
\hline 65 & 33 & 5 & 55 & 41 & 44 \\
\hline 63 & 32 & 4 & - & - & - \\
\hline 58 & 29 & 4 & 51 & 26 & 38 \\
\hline 45 & 23 & 3 & 39 & 20 & 32 \\
\hline 26 & 13 & 2 & - & - & - \\
\hline 21 & 12 & 1 & - & - & - \\
\hline
\end{tabular}

*Obtained by totalling the first column and dividing that total into the number of respondents per subct. May be interpreted as number of pages per 100 pages or articles per 100 articles or pictures per 100 ctures on the subject. 
It would seem from this voting that the average respondent is interested in many aspects of natural history and in preserving hịs environment, including its flor: and fauna. Another indication of this wide range of interest is that $98 \%$ of those who wanted bird articles also wanted to read about other subjects.

Favourite Articles: Seventy-nine articles, notes and columns were listed amon the best liked. Sixteen articles received more than 10 votes each. Their ab breviated titles, with the number of votes in parentheses, were: Coyot management in Saskatchewan (56), Whooping Crane in Saskatchewan (29), Com mon insect galls (29), Botanical investigation of the Drumheller area (20) Cougar kittens (20), Biological and chemical study of Qu'Appelle Lakes (19) Birdwatching indoors (18), Short-faced Bear (14), Captive Poor-will in Albert (16), Letters and notes (15), Feeding the hungry (14), Goldeneyes at Emma Lak (13), Ste. Scholastique Airport (12), Animals of the Pinhorn Grazing Preserv (12), Then and now (Marion Nixon) (12), and Plea for protection of the Aiyans! lava flow (11).

Most of the reasons for liking articles are covered by "interesting", "infor mative", "educational", "well done", "readable" and "am familiar with the area".

Occupation: There were about 50 occupations listed by 182 people. The mos frequent were: 31 housewives, 25 students, 22 active and 3 retired teachers an 23 farmers. Persons who were professionals in the subjects listed in the abovi table (biologists, veterinarians, conservation officers, archaeologists, etc. totalled 24.

\section{Age of Respondents:}

$\begin{array}{lll}\text { 10-19 years: } 14 & 20-29 \text { years: } 29 & 30-39 \text { years: } 25 \\ 40-49 \text { years: } 33 & 50-59 \text { years: } 40 & 60-69 \text { years: } 31 \\ 70-79 \text { years: } 11 & 80-89 \text { years: } 5 & 90-99 \text { years: } 1\end{array}$

This tabulation shows that only one-third of the respondents were under 40 . Ot viously we did not find out what would make the Blue Jay more attractive younger readers, particularly high school students.

Geographical Distribution: Not everyone stated where they lived but of thos who did, there were 127 from Saskatchewan, 29 from Alberta, 17 frot Manitoba, 10 from elsewhere in Canada and 4 from the United States.

Comments: There was a great variety of comments on many subjects. Most con monly mentioned were: new format ( 21 for, 2 against), emphasis on commo names ( 21 for, 9 against), March cover ( 7 for, 8 against).

Summary: It looks as though the Blue Jay must continue to cover a wide range subjects, but with a better balance among them. This, in turn, means that ou readers, particularly our respondents, will have to help themselves by writin and encouraging others to write letters, notes and articles on their experiencr and ideas, and by sending in photographs and drawings of plants, mammals, cor servation topics, etc. etc.

Thanks again for your cooperation. - J. B. Gollop. 